\title{
Milletlerarası Tahkim Kanunu Çerçevesinde Kira Sözleşmelerinin Tahkime Elverişliliği
}

\author{
Arbitrability of Tenancy Contracts within the Scope of the International \\ Arbitration Act
}

\author{
Hatice Selin Pürselim *iD
}

\section{öz}

Genel hatlarıyla tahkim, irade serbestisi prensibine yer veren, devlet mahkemelerinde görülen yargılamaya kıyasen daha hızlı ilerleyen, gizlilik ilkesine hizmet eden, ihtilafın o alandaki uzman kişilerce nihayete erdirilmesini hedefleyen bir yargılama usulüdür. Tahkim yargılamasının yapılabilmesi için asli unsurlardan biri uyuşmazlığın tahkime elverişli olmasıdır. Tahkime elverişlilik, ilgili ülkelerin milli hukuklarına göre değişiklik göstermektedir. Tahkime elverişlilik hususu sadece konu itibarıyla sınırlı değildir; fakat çalışmamızın kapsamı nedeniyle elverişlilik kavramı sadece uyuşmazlığın konusu açısından ele alınacak ve burada da bir sınırlamaya gidilerek kira sözleşmelerinin bu çerçevede değerlendirilip değerlendirilemeyeceği tartışılacaktır. Zira 4686 sayılı ve 21.06 .2001 kabul tarihli Milletlerarası Tahkim Kanunu (MTK) md. 1/4'te Türkiye’de bulunan taşınmaz mallar üzerindeki ayni haklara ilişkin uyuşmazlıklar ile iki tarafın iradelerine tabi olmayan uyuşmazlıklarda tahkime gidilemeyeceği düzenlenmiştir. Şayet kira sözleşmesi MTK md. 1/4 kapsamında tahkime elverişli değilse kararın MTK md. 15/A/2/a uyarınca iptali söz konusu olacağından bu tespitin önem taşıdığı kanaatindeyiz. Çalışmada kira sözleşmesinin niteliği üzerinde durularak ilgili Yargıtay kararlarına ve doktrin tartışmalarına yer verilecektir.

Anahtar Kelimeler: Tahkim, Tahkim yeri, Kira sözleşmesi, Tahkime elverişlilik, Milletlerarası Tahkim Kanunu

\section{ABSTRACT}

Arbitration, in general terms, is a dispute resolution mechanism which places emphasis on party autonomy, provides for quicker proceedings compared to state courts, attaches importance to preserving confidentiality and aims for resolution of disputes by arbitrators competent in the relevant field. One of the main prerequisites of arbitration is that the dispute should be capable of being settled by arbitration. Law systems have different approaches with regard to arbitrability. Arbitrability is not limited to the nature of the disputes. However, in our study, we will only be discussing arbitrability with regard to the nature of the dispute and within this context, we will be limiting this study to the question of whether tenancy agreements are arbitrable. Under Article 1/4 of the Turkish International Arbitration Act (MTK) numbered 4686 and dated 21.06.2001, it is stipulated that disputes arising from rights in rem in immovables that are located in Turkey and disputes that are not within the parties' disposal cannot be resolved by way of arbitration. If a tenancy dispute is not arbitrable pursuant to Article $1 / 4$ of MTK, then the arbitral award shall be subject to annulment in accordance with Article 15/A/2/a of MTK. For this reason, determining the arbitrability of tenancy disputes is important. In this study, the legal nature of tenancy contracts as well as the relevant Court of Cassation decisions and scholarly discussions in this field will be examined.

Keywords: Arbitration, Seat of arbitration, Tenancy contracts, Arbitrability, International Arbitration Act

* Doç. Dr., Marmara Üniversitesi Hukuk Fakültesi Milletlerarası Özel Hukuk Anabilim Dalı Sorumlu Yazar/Correspondence Author: Hatice Selin Pürselim

E-posta/E-mail: hselinpurselim@marmara.edu.tr 


\section{GENEL OLARAK}

Milletlerarası ticaret yaşamının ihtiyaçları, ilerlemesi ve potansiyel ihtilaflar karşısında, milletlerarası tahkim sınırlar ötesi ticarette ortaya çıkan uyuşmazlıkların nihayete kavuşturulmasında önemli bir çözüm yoludur ${ }^{1}$. Yabancılık unsuru taşıyan ${ }^{2}$, tahkim yerinin Türkiye olarak belirlendiği veya 4686 sayılı ve 21.06.2001 kabul tarihli Milletlerarası Tahkim Kanunu³ (MTK) hükümlerinin taraflar veya hakem kurulunca seçildiği uyuşmazlıklarda milletlerarası tahkimin esaslarını ve usulünü düzenleyen MTK uygulanacaktır; ancak Türkiye Cumhuriyeti’nin taraf olduğu milletlerarası antlaşma hükümleri her hâlükârda saklı tutulacaktır (MTK md. 1). MTK şüphesiz ki son yıllarda Türk hukuk uygulamasında önemli bir yere sahiptir. Ancak milletlerarası tahkim uygulamaları tüm dünyada olduğu gibi Türk hukukunda da belirli noktalarda tartışmalı meseleleri barındırmaktadır. Yargıtay, kira sözleşmelerine dair uyuşmazlıklarda zayıf tarafın korunması ilkesinden hareket etmektedir. Çalışmamızın amacı, kira sözleşmesiyle zayıf tarafın korunan hakkının barınma hakkı kapsamında değerlendirildiğinde tahkime elverişli olup olmadığını tartışmaya açmaktır.

\section{TAHKIM TANIMI}

Tahkim doktrinde farklı şekillerde tanımlanmıştır. Ancak hemen her tanımda yer alan karakteristik unsurlar kapsamında genel bir tanım yapılırsa, tahkimin, tarafların kendi rızalarıyla aralarındaki uyuşmazlığı kesin ve bağlayıcı olarak nihayete erdirmeleri için hakem yargılamasına başvurmaları ve bu yol vasıtasıyla çözüm aramaları olduğunu söyleyebiliriz. Doktrinde yapılan detaylı tanımlara baktığımızda tahkimin, kanunun tahkim yoluyla çözümlenmesine müsaade ettiği konular kapsamında olmak şartıyla, iki veya daha fazla şahısın arasında, bir hak üzerinde doğmuş veya doğabilecek uyuşmazlıkların mahkeme yerine hakem adı verilen kimseler aracılığı ile kesin ve bağlayıcı şekilde çözümlenmesi konusunda tarafların anlaşmaları şekilde tanımlandığı görmekteyiz ${ }^{4}$.

1 Tanrıbilir, Feriha Bilge/Şit, Banu, Milletlerarası Tahkim Müessesesi ve Yeni Milletlerarası Tahkim Kanunu, MHB, Yıl 22, 2002, s. 821.

2 Nomer, Ergin, Devletler Hususi Hukuku, İstanbul 2017, s. 583; Öztekin Gelgel, Günseli, Milletlerarası Tahkim Kanununun Uygulama Alanı ve Getirmiş Olduğu Önemli Yenilikler, Bilgi Toplumunda Hukuk, Ünal Tekinalp’e Armağan, 2003, s. 1081 vd.; Özdemir Kocasakal, Hatice, Milletlerarası Tahkim Kanununun Uygulama Alanının Belirlenmesi, Prof. Dr. Özer Seliçiłye Armağan, Ankara 2006, s. 346 vd.; Aybay, Rona/Dardağan, Esra, Uluslararası Düzeyde Yasaların Çatışması, İstanbul 2008, s. 333; Nomer, Ergin, Milletlerarası Usul Hukuku, İstanbul 2018, s. 266 vd.; Çelikel, Aysel/Erdem, B. Bahadır, Milletlerarası Özel Hukuk, İstanbul 2020; Şanlı, Cemal/Esen, Emre/Ataman Figanmeşe, İnci, Milletlerarası Özel Hukuk, İstanbul 2021, s. 768.

3 RG. 05.07.2001/24453.

4 Ansay, Sabri Şakir, Hukuk Yargılama Usulleri, Ankara Hukuk Fakültesi Yayınları, Ankara 1960, s. 404; Alangoya, Yavuz, Medeni Usul Hukukumuzda Tahkimin Niteliği ve Denetlenmesi, İstanbul 1973, s. 4; Akıncı, Ziya, Milletlerarası Tahkim, İstanbul 2020, s. 3 vd.; Özel, Sibel, Milletlerarası Ticari Tahkimde Kanunlar İhtilafı Meseleleri, İstanbul 2008, s. 31; Alangoya, Yavuz/Yıldırım, M.Kâmil/Deren Yıldırım, Nevhis, Medeni Usul Hukuku Esasları, İstanbul 2009, s.596; Şanlı, Cemal, Milletlerarası Hakem Kararı-Milletlerarası Ticari Tahkimde Usule Uygulanacak Hukuk Tarafların Tahkim Hukukunu Seçme Yetkisi-Hakem Kararının İptali Davasının Tenfize Etkisi - Tahkim Yeri ve Mahalli Mahkemeler Arasındaki İlişkiler, MHB, Cilt 3, Sayı: 1, 1983, s. 25; Tekinalp, Gülören, Milletlerarası Özel Hukuk Bağlama ve Usul Hukuku Kuralları, İstanbul 2020, s. 445; Doğan, Vahit, Milletlerarası Özel Hukuk, Ankara 2020, s. 163; Güngör, Gülin, Türk Milletlerarası Özel Hukuku, Ankara 2021, s. 305; Çelikel/Erdem, s. 816; Şanlı/Esen/Ataman Figanmeşe, s. 758; Şanlı, Cemal, Uluslararası Ticari Akitlerin Hazırlanması ve Uyuşmazlıkların Çözüm Yolları, İstanbul 2016, s. 292; Postacioğlu, İlhan, Medeni Usul Hukuku Dersleri, İstanbul 2015, s. 1026; Kuru, Baki, Hukuk Muhakemeleri Usulü, Cilt 
Tahkimin amacı, uzman kişi olan hakemlerin söz konusu uyuşmazlığı hızlı, ihtiyaçlara uygun ve gizlilik içerisinde çözmeye çalışmalarıdır 5 . "Anlaşanların", diğer bir ifadeyle, tahkim anlaşmasına taraf olan kişilerin, söz konusu ilişkiye dair tahkimin kapsamına giren bir ihtilafın ortaya çıkması halinde prensip olarak tahkim yargılamasına katılmaları gerekecektir. Tarafların tahkime gideceğine dair yapılan kararlaştırma ayrı bir sözleşme şeklinde yapılabilir veyahut esas sözleşmeye tahkim şartı şeklinde eklenebilir. Tahkimin incelememiz açısından önem arz eden noktası, esas sözleşmenin içinde yer alan tahkim şartı veya esas sözleşmeden ayrı olarak hazırlanan tahkim sözleşmesi kapsamında kira sözleşmelerine ilişkin uyuşmazlıkların tahkime elverişli olup olmadığıdır.

\section{TAHKIME ELVERIŞLILIK}

Her uyuşmazlık birbirinden farklı bir hukuki yapıya sahiptir. Bu nedenle hangi uyuşmazlıkların tahkim yoluyla çözüleceğine hangilerinin çözülemeyeceğine tahkime elverişlilik şemsiyesi altında karar verilmektedir. Tahkime elverişli olan ihtilaflar tahkim yoluyla çözülebilirken, bu şemsiye altına giremeyen ihtilaflar için tahkim yolu mümkün görünmemektedir. Tahkime elverişlilik, genel olarak bir uyuşmazlığın/konunun tahkim yargılamasında görülüp görülemeyeceğini ifade etmektedir; diğer bir ifadeyle bu kavram "ne için" tahkim yargılaması yapılıp yapılamayacağını işaret etmektedir6́.

Tahkime elverişliliğin tespitinde ihtilafa hangi hukukun uygulanacağı önem arz eder ${ }^{7}$. İncelememizin kapsamına girmediği için kısaca belirtmek isteriz ki tahkime elverişliliğin muhtemel tenfiz ülkesi dikkate alınarak tespit edilmemesi gerektiğini savunan görüşe katılmaktayız; aksi halde tahkim yeri hukuku uyarınca tahkime elverişli olan bir uyuşmazlık, muhtemel tenfiz ülkesi hukuku uyarınca tenfize elverişli değilse hakemler uyuşmazlı̆̆ı çözmekten imtina edeceklerdir ${ }^{8}$. Tarafların hakemlere verdiği yetki dikkate alındığında bu halin bir çelişki yarattığı fikrine katılmaktayız ${ }^{9}$. Tahkime

VI, İstanbul 2001, s. 5875; Tiryakioğlu, Bilgin, Yatırım Tahkiminde Konu ve Kişi Bakımından Yetki, Ed. Süral Efeçınar, Ceyda/Ömeroğlu, Ekin/Uyanık, Ece, Uluslararası Yatırım Tahkimi ve Üçüncü Kişi Finansmanı, Ankara, 2018, s. 11; Nomer, Ergin, Hakem Kararının Kamu Düzenine Aykırılığı ve Tahkim Anlaşmasının Geçerliliği, MHB, Cilt 10, Sayı: 1-2, s. 130 vd.; Erkan, Mustafa, Tahkim Şartının Ayrılabilirliği Prensibinin Asıl Sözleşmenin Yokluğu Durumunda Değerlendirilmesi, Gazi Üniversitesi Hukuk Fakültesi Dergisi C. XVII, 2013/ 1-2, s. 536; Hamann, Hartmut/Lennarz, Thomas, Schiedsverfahren oder staatliche Gerichtsverfahren - Was ist besser?, Stuttgart JA, 2012, s. 801 vd.

5 Giray, Faruk Kerem, Milletlerarası Tahkimde Gizlilik, Uluslararası Ticaret ve Tahkim Hukuku Dergisi, S. 2015/2, s. 65 vd; Çelikel/Erdem, s. 816.

6 Özel, s. 38; Özel, Sibel, Yabancı Hakem Kararlarının Tenfizine Engel Bir Durum: Tahkim Sözleşmesinin Geçersiz Olması, MÜHF - HAD, C. 23, S. 1, s. 317; Huysal, Burak, Milletlerarası Ticari Tahkimde Tahkime Elverişlilik, İstanbul 2010, s. 12 vd.; Esen, Emre, Uluslararası Tahkime Tabi Bir Uyuşmazlı̆̆ın Devlet Mahkemelerine Götürülmesi Halinde Tahkim Anlaşmasının Geçerliliğine İlişkin İtirazların İncelenmesi ve Kompetenz-Kompetenz Prensibi, Galatasaray Üniversitesi Hukuk Fakültesi Dergisi (Prof. Dr. Ata Sakmar’a Armağan), 2011, s. 355 vd.; Özkan, Işı1/Tütüncübaşı, Uğur, Uluslararası Usul Hukuku, Ankara 2017, s. 269.

7 Özel, s. 39. Tahkime elverişliliğe uygulanacak hukukla ilgili tartısmalar için bkz. Tüysüz, Cemre, Milletlerarası Ticari Tahkim Açısından İcra ve İflas Hukukundaki Davalar, İstanbul 2017, s. 26 vd.

8 Özel, s. 58. Ayrıca bkz. Doğan, Vahit, Tahkime Elverişlilik Bağlamında Yabancı Unsur, Ed. Doğan, Vahit/Yılmaz, Alper Çağrı/İzmirli, Lale Ayhan, Milletlerarası Özel Hukukta Güncel Meseleler Sempozyumu, Antalya Bilim Üniversitesi Hukuk Fakültesi, Ankara 2019, s. 449 vd.

Özel, s. 58. 
elverişsiz bir konuda verilen hakem kararının iptali gündeme gelebileceğinden, bu meselelerde tahkime gidilmesinin zaman ve masraf kaybına neden olacağı düşünülmektedir ${ }^{10}$.

Mahalli hukuklar tahkime elverişlilik ile ilgili sınırlamalarını kendileri koymaktadır. Mahalli hukukların bu sınırlamaları koyarken milletlerarası sözleşmeleri dikkate alarak ve usul hukukuna hâkim temel ilkeler ışığında taraf iradelerine sınırlı sayıdaki emredici kurallarla müdahale ettiği bilinmektedir ${ }^{11}$. Tarafların kendi iradesine tabi olan ve onların üzerinde kabul/sulh yoluyla serbestçe tasarruf edebilecekleri konulardan kaynaklanan uyuşmazlıklar tahkime elverişli kabul edilmektedir ${ }^{12}$. Tahkime elverişli uyuşmazlıkların konu bakımından sınıflandııılması objektif tahkime elverişlilik (ratione materiae); ehliyet ve temsil yönünden sınıflandırılması ise sübjektif tahkime elverişlilik (ratione personae) denilmektedir ${ }^{13}$. Objektif tahkime elverişlilik kamu düzeni kavramı ile somut hale gelebileceğinden, objektif tahkime elverişlilik kavramı kamu düzeninin “ikiz kız kardeşı” olarak tanımlanmaktadır ${ }^{14}$.

Hukuk sistemlerinde tahkime elverişliliğin tespiti için farklı usuller belirlenmiştir. Tahkime elverişliliğin tespiti için ekonomik faaliyetlerle sınırlandırma yapılmış veya tarafların üzerinde tasarruf edebilecekleri haklara dair bir sınır çizilmiş veyahut tarafların üzerinde tasarruf edebilecekleri haklara dair bir belirleme yapılarak istisnalar açıkça zikredilmiş olabilir ${ }^{15}$. Tahkime elverişliliğin belirlenmesinde şüphesiz ki o devletin siyasi, sosyal ve ekonomik durumu önemli rol oynamaktadır. Devletlerin siyasi, sosyal ve ekonomik durumlarının da zaman içerisinde gelişeceği ve değişeceği unutulmamalıdır. Bu nedenle, tahkime elverişlilik de zaman içerisinde kendini yenileyecek, günümüzde tahkime elverişli kabul edilmeyen konular ileride elverişli kabul edileceği gibi tahkime elverişsiz kabul edilen konular da tahkime elverişli hale gelebilecektir ${ }^{16}$. Sonuç olarak, tahkime elverişlilik konusunda milli hukuklarda öngörülen sınırlamaların gerekçeleri, kanun koyucunun tahkim yargılamasına bakış açısına, kendi sosyal ve ekonomik sistemine ve kamu düzeni anlayışına göre değişmektedir ${ }^{17}$.

10 Akıncı, Ziya, Milletlerarası Ticari Uyuşmazlıkların Alternatif Çözüm Yolları, BATIDER 18/4, 1996, s. 109. Ayrıca bkz. Nomer, s. 588 vd. Tiryakioğlu, Bilgin, Milletlerarası Tahkim Kanununa Göre Hakem Kararlarının İptali, Milletlerarası Özel Hukukta Güncel Konular Sempozyumu, Anadolu Üniversitesi Hukuk Fakültesi, Ankara 2016, s. 301 vd., Liebscher, Christoph, Objektive Schiedsfähigkeit-Eine Skizze, Dokuz Eylül Üniversitesi Hukuk Fakültesi Dergisi, C. 16, Özel Sayı 2014, Prof. Dr. Hakan Pekcantteze Armağan, 2015, s. 1625; Nomer, Usul, s. 272 vd.

11 Şanl, Cemal, Milletlerarası Ticari Tahkimde Esasa Uygulanacak Hukuk, Ankara 1986, s. 123 vd.

12 Şanl, Ticari Akitler, s. 467; Doğan, s.180; Özdemir Kocasakal, Hatice, Doğrudan Uygulanan Kurallar ve Sözleşmeler Üzerindeki Etkileri, İstanbul 2001, s. 179.

13 Özel, s. 38; Liebscher, s. 1625 vd.; Şanlı/Esen/Ataman Figanmeşe, s. 767 vd.; Erkan, Mustafa, Milletlerarası Tahkimde Yetki Sorunları, Ankara 2013, s. 75; Huysal, s. 14; Özkan/Tütüncübaşı, s. 242 vd.; Tüysüz, s. 12 vd.; Ersen Perçin, Gizem, MTK Tahkiminde İptal Davalarına İlişkin Bir Değerlendirme, PPIL 40/2, (Cemal Şanlı Armağanı), 2020, s. 1068; Münch, Joachim, in: Münchener Kommentar zur ZPO, München 2017, Rn. 11; Wächter, Vincent, Die Schiedseinrede bei Auslandsberührung, Tübingen 2020, s. 64-65.

14 Liebscher, s. 1634 vd.

15 Özel, s. 51 vd.; Şanlı/Esen/Ataman Figanmeșe, s. 758; Şanlı, Ticari Akitler, s. 468; Poloni, Flore, Tahkim Talebine Cevap, Ed. Akıncı, Ziya/Greineder, Daniel/Yasan Tepetaş, Candan, Tahkimde Davanın Açılması: İlk Dilekçeler ve Hakem Seçimi, İstanbul 2020, s. 15 vd.; Özkan/Tütüncübaşı, s. 281.

16 Aynı yönde bkz. Tüysüz, s. 19; Erkan, Yetki, s. 75; Takavut, İbrahim Doğan, Milletlerarası Ticari Tahkimde Doğrudan Uygulanan Kurallar, İstanbul 2018, s. 79 vd.

17 Şanll, Ticari Akitler, s. 468. 


\section{MTK KAPSAMINDA TAHKIME ELVERIŞLILIĞiN KIRA SÖZLEŞMELERi YÖNÜNDEN DEĞERLENDIRILMESI}

\section{A. INCELEMENIN KAPSAMI}

MTK md. 1'de Türkiye'de bulunan taşınmaz mallar üzerindeki ayni haklara dair uyuşmazlıklar ile iki tarafın iradesine tabi olmayan uyuşmazlıkların tahkime elverişli olmadığı yer almaktadır.

Bu madde uyarınca, Türkiye’de bulunan taşınmazlar üzerindeki ayni haklara ilişkin uyuşmazlıklar ile iki tarafın iradelerine tabi olmayan meselelerde tahkime gidilemeyecektir. Belirli ihtilafların tahkim yargısına kapatılması kamu düzenini koruma düşüncesine dayanmaktadır ${ }^{18}$. Taşınmazın aynına ilişkin olmayan kira sözleşmelerinde tahkime gidilip gidilemeyeceği tartışmalıdır ${ }^{19}$. Kira sözleşmesi rızai ve tam iki taraf borç yükleyen, günlük hayatta sıklıkla karşılaştığımız bir sözleşme tipidir. $\mathrm{Bu}$ sözleşme tipi acaba işçiyi ve tüketiciyi koruma amacıyla tahkime izin verilemeyen yani zayıf tarafın korunduğu sözleşmeler grubuna dahil midir? Tahkim şartı konulmuş kira sözleşmesinden doğan ihtilaf sebebiyle zayıf konumda olduğu kabul edilen kiracının tahkime başvurması tahkime elverişliliği sağlayacak mıdır? Kira sözleşmelerinde Yargıtay’’n benimsediği tacirler arası kira sözleşmeleri/tacir olmayanlar arası kira sözleşmeleri şeklinde bir ayrımın yapılması zorunlu mudur? Kira sözleşmesinden doğan ihtilafların tahkime elverişli olup olmadığı bir bütün halinde ele alınabilir. Ancak bu anlayış kira sözleşmesinden doğan ihtilafların aynı nitelikte kabul edilmesine hizmet edebilir. Bu yöntem yerine talepler tahliye, kira bedelinin tespiti ve kira alacağının tahsili şeklinde üçe ayrılarak her bir talebin ayrı ayrı tahkime elverişliliği incelenebilir. Kira sözleşmesinin bir bütün halinde ele alınması mı yoksa ihtilaf konusuna göre sınıflandırılarak tahkime elverişliliklerinin araştırılması mı tercih edilmelidir? Aşağıda bu hususlar tartışmaya açılarak doktrindeki tartışmalara ve Yargitay kararlarına yer verilecektir.

\section{B. KIRA SÖZLEŞMESININ NITELIĞi}

Türk Borçlar Kanunu (TBK) md. 299 kira sözleşmesini düzenlemektedir. TBK md. 299 uyarınca, kira sözleşmesi, kiraya verenin bir şeyin kullanılmasını veya kullanmayla birlikte ondan yararlanılmasını kiracıya bırakmayı, kiracının da buna karşılık kararlaştırılan kira bedelini ödemeyi üstlendiği sözleşmedir. Rızai ve sürekli borç doğuran bir sözleşme olan kira sözleşmesinin tam iki tarafa borç yükleme vasfı nedeniyle, kiraya veren kiralananı kiracıya kullanıma elverişli bir şekilde teslim etme ve kira süresi boyunca bu durumda bulundurma borcu altındadır; kiracı ise kira konusunu kullanımı karşılığında kira bedelini ödeme yükümlüğü taşımaktadır ${ }^{20}$. Sözleşme herhangi bir şekle tabi değildir;

18 Şanl, Ticari Akitler, s. 469.

19 Özel, s. 53.

20 Akartepe, Alpaslan, Türk Borçlar Kanunu’nun 315. Maddesi Çerçevesinde Kiracının Kira Bedelini Ödemede Temerrüdü ve Hukuki Sonuçları, MÜHF - HAD, Prof. Dr. Cevdet Yavuz’a Armağan Özel Sayısı, C: 22, S: 2016/3, s. 85; Kırmızı, Mustafa, 6098 Sayılı Yasada Konut ve Çatılı İşyeri Kiraları, Ankara 2013, s. 39; Kaynar, Muhammet, Konut ve Çatılı İşyeri Kiralarında Kira Bedelinin Belirlenmesi, İstanbul 2014, s. 4; Aral, Fahrettin/Ayrancı, Hasan, Borçlar Hukuku Özel Borç İlişkileri, Ankara 2015, s. 48 vd.; Münch, Rn. 29. 
zımni olarak dahi yapılsa geçerli olduğu ifade edilmektedir ${ }^{21}$. Şüphesiz ki kira bedeli sözleşmenin asli edimlerinden biridir ve taraflar irade serbestisi gereği bu bedeli özgürce kararlaştırabilir ${ }^{22}$. Kirac1, aksine sözleşme ve yerel adet olmadıkça, kira bedelini ve gerekiyorsa yan giderleri, her ayın sonunda ve en geç kira süresinin bitiminde ödemekle yükümlü olacaktır (TBK md. 314).

Kiraya veren ve kiracı arasındaki ilişkide, prensip olarak kiraya verenin üstün durumda olduğu kabul edilerek, zayıf tarafın korunması hedeflenmiştir ${ }^{23}$. Örneğin, kiracının zayıf konumda olmasından hareketle TBK’nın kiracıyı koruma vasfı taşıyan kira bedelinin belirlenmesine ilişkin hükümlerin kamu düzenine ilişkin olduğu kabul edilmektedir ve bu nedenle TBK’nın kira bedelinin belirlenmesine dair 344. ve 345. maddelerinin ivedilikle yürürlüğe girdiği ve hatta TBK yürürlüğe girmeden önce kurulmuş olan sözleşmelere de uygulandığı ifade edilmiştir ${ }^{24}$.

Kullandırma amacı güden kira sözleşmesinden kaynaklanan ihtilaflar; alacağın tahsili, kira bedelinin tespiti ve tahliye taleplerinden doğmaktadır ${ }^{25}$. Kira bedelinin tespitinde kiraya veren ile kiracı arasında adil bir dengenin sağlanması, yararlar dengesine uygun bir çözüm bulunması önerilmektedir; her ne kadar kira bedeli taraflarca serbestçe tayin edilse de sözleşmenin yapılmasından sonra kiraya verenin kötü niyetle hareket etmesi mümkündür ${ }^{26}$. Kiracının baskı altında kalarak kişisel veya ailevi veyahut iş piyasasındaki zorluklar nedeniyle sözleşme yapması muhtemeldir ${ }^{27}$. Anayasa Mahkemesi’nin mülga 6570 sayılı Gayrimenkul Kiraları Hakkında Kanun'un 2. ve 3. maddelerini kira bedelinin kamu yararına uygun olarak sınırlanabileceği görüşüne dayanarak iptal etmesinin ${ }^{28}$ devamında ortaya

21 Tunaboylu, Müslim, Kira Sözleşmesinde Fesih ve Tahliye Davaları, Ankara 2013, s. 155 vd..

22 Eren, Fikret, Borçlar Hukuku Özel Hükümler, Ankara 2017, s. 320; Yavuz, Cevdet/Acar, Faruk/Özen, Burak, Türk Borçlar Hukuku Özel Hükümler, İstanbul 2014, s. 381 vd..

23 Eren, s. 393; Yavuz/Acar/Özen, s. 591; Akyiğit, Ercan, 6098 sayılı Türk Borçlar Kanunu’nda Kira Sözleşmesi, İstanbul 2012, s. 139.

24 Kılıç Öztürk, Gamze, Kira Tespit Davası ve Esasları, TBB Dergisi, 2017/129, s. 12.

25 Kira sözleşmesiyle ilgili detaylı bilgi için bkz. Acar, Faruk, Kira Hukuku Şerhi, (TBK m. 299-321), Yenilenmiş ve Genişletilmiș 2. Baskı, İstanbul 2015, md. 299/ 54 vd.; Koç, Nevzat, 6098 Sayılı Türk Borçlar Kanununda Kira Sözleşmesine İlişkin Olarak Yapılan Yeni Düzenlemelerin Genel Değerlendirmesi, İstanbul Medipol Üniversitesi Hukuk Fakültesi Dergisi 1 (1), Bahar 2014, s. 10; İnceoğlu, M. Murat, Kira Hukuku, İstanbul 2014, s. 8 vd.; Gümüş, M. Alper, 6098 Sayılı Borçlar Kanununa Göre Kira Sözleşmesi, İstanbul 2011, s. 26 vd..

26 Kılıçoğlu, Ahmet M., Kira Bedellerinin Dondurulması Yasası ve Eleştirisi, Türkiye Barolar Birliği Dergisi, 2000/2, s. 409.

27 Kilıçoğlu, Ahmet M., s. 407.

28 AYM 26.03.1963 tarihli E. 1963/3, K. 1963/67 (RG. 31.05.1963/11416); “(..) Anayasa’nın 36 ncı maddesinde, herkesin mülkiyet ve miras haklarına sahip olduğu, bu hakların, ancak kamu yararı amacı ile kanunla sınırlanabileceği, mülkiyet hakkının kullanılmasının toplum yararına aykırı olamıyacağı, yazılıdır. Bu suretle Anayasa, mülkiyet hakkının, kanunla ve kamu yararı amacı ile sınırlanabileceği esasını koymuş bulunmaktadır. Bununla beraber, yine temel hak ve hürriyetlerin Anayasa’nm sözüne ve ruhuna uygun olarak ancak kanunla sinırlanabileceğini ve kanunun kamu yararı, genel ahlak, kamu düzeni, sosyal adalet ve milli güvenlik sebepleri ile de olsa bir hakkın ve hürriyetin özüne dokunamıyacağını emreden Anayasa’nın 11 inci maddesinin, mülkiyet hakkının sınırlandırılmasında da gözönünde bulundurulması zorunluğu vardır. (...) Gayrimenkullerin, mesken ve iş yeri olarak çeşitli yönler toplumu ilgilendiren büyük önemi vardır. Bu yönlerden birisi de iktisadi alandır. Mesken ve iş yeri darlığının bulunduğu memleketlerde, Devletçe tedbir alınmadığ 1 takdirde, talebin fazlalığ 1 dolayısiyle kiralar anormal şekilde yükselir. Bu yükseliş istihlak maddelerinin fiyatları üzerinde de etkilerini gösterir ve hayat pahalılığına sebep olur. Bu gerçek birçok yabancı memleketlerde de kabul edilmiş ve kira konusunda çeşitli tedbirler alınmıştır. Memleketimizde de ilk defa Milli Korunma Kanunu’nda yer alan 30. madde ile kiralar dondurulmuş, sonradan bu maddenin ihtiyacı karşılayamadığı görülerek değişiklikler yapılmış ve son olarak 1/6/1955 gününde yürürlüğe giren 6570 sayılı kanun kabul edilmiştir. Hayat pahalılığı, toplumda huzursuzluk yaratan bir olaydır. Toplumu buna karşı korumak amacı ile Devletçe tedbir alınmasının kamu yararına 
çıan ve kira sözleşmelerinde kira bedelinin belirlenmesi konusunda 1963 yılından itibaren Yargıtay kararlarıyla doldurulmaya çalışılan boşluk TBK md. $344^{29}$ ile giderilmeye çalışılmıştı ${ }^{30}$. Uygulamada tespit davası olarak bilinen, kira bedelinin belirlenmesi davasının açılma süresi ve mahkemece belirlenen kira bedelinin hangi tarihten itibaren kiracıyı bağlayıcı etkisinin olacağına ilişkin olarak önceki BK'da ve mülga 6570 sayılı Gayrimenkul Kiraları Hakkında Kanunun 2. ve 3. maddelerinin iptalinden sonra da yasal bir düzenleme konusu yapılmadığı; mevcut TBK'nın 345. maddesinde bu meselenin de çözüme erdirildiği ifade edilmektedir ${ }^{31}$. Ayrıca TBK’nın 346. maddesinde düzenlenen kiracı aleyhine düzenleme yasağının kiracının korunması ilkesine uygun olduğu savunulmaktadır ${ }^{32}$ : TBK md. 346 uyarınca, kiracıya, kira bedeli ve yan giderler dışında başka bir ödeme yükümlülüğü getirilemeyecektir; özellikle, kira bedelinin zamanında ödenmemesi halinde ceza koşulu ödeneceğine veya sonraki kira bedellerinin muaccel olacağına ilişkin anlaşmalar geçersiz olacaktır. TBK md. 346 düzenlemesiyle, Yargıtay’n, kira sözleşmelerine konulan muacceliyet kaydının geçerli olduğunu kabul eden içtihadının 1 Temmuz 2012 tarihi itibarıyla geçerliliğini yitirdiği ifade edilmektedir ${ }^{33}$.

\section{KIRA SÖZLEȘMESININ TAHKIME ELVERIŞLIĞINE DAIR TARTIȘMALAR}

MTK md. 1/4 uyarınca Türkiye'de bulunan taşınmazın aynına dair uyuşmazlıklar Türk hukuku açısından tahkime elverişli değildir. Akıncı, yabancı ülkede bulunan taşınmazla ilgili uyuşmazlığın niteliği, kararın tenfiz edileceği yani taşınmazın bulunduğu ülke hukuku bakımından tahkime elverişli sayılıyorsa tahkim şartını geçersiz kılmak için bir sebep olmadığını ve uyuşmazlı̆̆ın tahkime elverişli kabul edilmesi gerektiğini ifade etmektedir ${ }^{34}$. Yazar, Türkiye’deki taşınmazların aynı ile ilgili uyuşmazlıkların tahkime elverişsiz olmasını Türk kamu düzeni kapsamında izah etmektedir;

bir müdahale teşkil ettiğinden şüphe edilemez. Aynı amaçla, kiraların kontrol altına alınması da kamu yararına olan tedbirler cümlesinden sayılmak icap eder. Devletin bu konudaki müdahalesi, mülkiyet hakkının kamu yararı amacı ile sınırlanabileceğini ön gören Anayasa’nın 36 ncı maddesinin kapsamına girer. Bu sebepler gözönünde tutularak, memleketimizde gayrimenkul darlığı devam ettiği sürece, ka - nun koyucunun, kira konusunu düzenlemesinin ve bu alanda sınırlama yapmasının, mülkiyet hakkının özüne dokunmamak şartı ile, caiz bulunduğu ve bu müdahalenin kamu yararına olduğu hususunda görüş birliğine varılmıştır (...)”.

tora dönemlerinde uygulanacak kira bedeline ilişkin anlaşmaları, bir önceki kira yılında üretici fiyat endeksindeki artış oranını geçmemek koşuluyla geçerlidir. Bu kural, bir yıldan daha uzun süreli kira sözleşmelerinde de uygulanır. Taraflarca bu konuda bir anlaşma yapılmamışsa, kira bedeli, bir önceki kira yılının üretici fiyat endeksindeki artış oranını geçmemek koşuluyla hâkim tarafından, kiralananın durumu göz önüne alınarak hakkaniyete göre belirlenir. Taraflarca bu konuda bir anlaşma yapılıp yapılmadığına bakılmaksızın, beş yıldan uzun süreli veya beş yıldan sonra yenilenen kira sözleşmelerinde ve bundan sonraki her beş yılın sonunda, yeni kira yllında uygulanacak kira bedeli, hâkim tarafından üretici fiyat endeksindeki artış oranı, kiralananın durumu ve emsal kira bedelleri göz önünde tutularak hakkaniyete uygun biçimde belirlenir. Her beş yıldan sonraki kira yllında bu biçimde belirlenen kira bedeli, önceki fikralarda yer alan ilkelere göre değiştirilebilir. Sözleşmede kira bedeli yabancı para olarak kararlaştırılmışsa, beş yıl geçmedikçe kira bedelinde değişiklik yapılamaz. Ancak, bu Kanunun, "Aşırı ifa güçlüğü" başlıklı 138 inci maddesi hükmü saklıdır. Beş yıl geçtikten sonra kira bedelinin belirlenmesinde, yabancı paranın değerindeki değişiklikler de göz önünde tutularak üçüncü fikra hükmü uygulanır”.

30 Koç, s. 25; K1lıç Öztürk, s. 7.

31 Koç, s. 26; Kılıç Öztürk, s. 10; Gökyayla, Emre, Konut ve Çatılı İş yeri Kiralarına İlişkin Hükümlerin Uygulama Alanı (TBK md. 339), Prof. Dr. Aydın Zevklilere Armağan, Cilt: 2, İzmir 2013, s. 1218.

32 Koç, s. 27.

33 Koç, s. 27.

34 Akıncı, s. $353 \mathrm{vd}$. 
bu nedenle, yabancı ülkedeki taşınmazların aynına dair ihtilafların Türk kamu düzeni ile ilgili olmadığını belirtmektedir ${ }^{35}$.

Yargitay, kat karşılloğ inşaat sözleşmelerinde tahkim şartı içeren sözleşmeye dayanarak yapılan tescil başvurularının tahkime elverişsiz olduğunu; kat karşılığı inşaat sözleşmelerinden doğan cezai şart taleplerinin ise tahkime elverişli olduğunu kabul etmektedir ${ }^{36}$. Taşınmazlarla ilgili meselelerde tahkime gidilebileceğini belirten 31.05.1979 tarihli Yargıtay kararı uyarınca, taşınmaz mal payının geri verilmesi amacıyla tapu sicilinde yapılması gerekli olan düzeltme işlemine dair dava, tarafların serbestçe gerçekleştirebilecekleri işlemlerden olması sebebiyle ve kamu düzenine ilişkin bir husus söz konusu olmadığından tahkim yoluyla çözülebilecektir ${ }^{37}$. Kira sözleşmeleriyle ilgili kararlara

\section{Akınc1, s. 353.}

36 Şanl, Ticari Akitler, s. 313 ve s. 470; "Yargıtay 15. Hukuk Dairesi E. 2010/1581 K. 2010/1652, Mahalli mahkemece verilen hükmün temyizen tetkiki davacı vekili tarafından istenmiş ve temyiz dilekçesinin süresi içinde verildiği anlaşılmış olmakla, dosyadaki kağıtlar okundu, gereği konuşulup düşünüldü: Dava, arsa payı karşıllığı inşaat sözleşmesinden kaynaklanan gecikme tazminatı ve kira bedeli istemine ilişkin olup, mahkemece tahkim şartı nedeniyle dava dilekçesinin görev yönünden reddine dair verilen karar davacı vekili tarafından temyiz edilmiştir. Taraflar arasında imzalanan 16.04.1993 tarihli 12477 yevmiye sayılı "Düzenleme Şeklinde Gayrimenkul Satış Vaadi ve Daire Karşllığı İnşaat Sözleşmesinin 13/2. maddesinde, sözleşmeden doğan ihtilafların halli için tahkim şartı kararlaştırılmasına karşın; davacı davasını mahkemede açmış olduğu gibi, davalı yüklenici şirket de aynı sözleşmeye dayanarak davacı $M$ ile diğer arsa sahipleri hakkında açtığı Antalya Asliye Birinci Ticaret Mahkemesi'nin 2008/257 Esas sayılı davasında cezai şartın tahsilini talep etmiştir. Görüldüğü üzere, davacı M tarafından açılan işbu temyize konu davada "tahkim" itirazında bulunan davalı yüklenici şirket, sözleşmedeki tahkim şartını dikkate almadan kendi davasını genel mahkemede açmışır. Geçerli tahkim sözleşmesi veya şartına rağmen sözleşmenin taraflarının davalarını hakem yerine mahkemelerde açmış olmaları durumunda tahkim sözleşmesinin veya şartının uygulanmasından vazgeçmiş olduklarının kabulü gerekir. Zira Türk Medeni Kanunu’nun 2. maddesi uyarınca herkes haklarını kullanırken ve borçlarını yerine getirirken dürüstlük kurallarına uymak zorundadır. Bir hakkın açıkça kötüye kullanılmasını hukuk düzeni korumaz. Taraflar sözleşmede kararlaştırılan tahkim şartının uygulanması olanağını ortadan kaldırmışlardır. Açıklanan bu sebeplerle davalılarca yapılan tahkim itirazı kabul edilemez. Mahkemece işin esasına girilerek uyuşmazlık çözüme bağlanmalıdır. Yukarıda açıklanan nedenlerle kararın bozulması uygun bulunmuştur. Sonuç: Yukarıda açıklanan sebeplerle davacı vekilinin temyiz itirazlarının kabulüne ve kararın davacı yararına (BOZULMASINA), ödediği temyiz peşin harcının istek halinde temyiz eden davacıya geri verilmesine, 23.03.2010 gününde oybirliğiyle karar verildi" (https://www.kararara.com/forum/viewtopic.php?f $=222 \& \mathrm{t}=246314$, 04.03.2021); Yargitay 15. HD. E. 2004/1798 E., K. 2004/5076, "Hakem tayini talep dilekçesinde, diğer taraf aleyhine hakem kurulunda açllacak davada, taraflar arasındaki gayrimenkul inşaat ve satış vaadi sözleşmesinin feshi ile tapu kaydı üzerindeki şerh ve takyidatların kaldırılması istemiyle dava açılacağından HUMK.nun 520. maddesi hükmünce karşı taraf hakeminin tayinine karar verilmesi istenilmiştir. Görülüyor ki, hakemde açılacak davada tapu kütüğündeki şerh ve takyidatların kaldırılmasının da istenileceği açıklanmıştır. Her ne kadar taraflar arasındaki sözleşmenin 10. maddesinde, bu sözleşmeyle ilgili ihtilafların tahkim yolu ile halledileceği kabul edilmiş ise de, tapu kütüğündeki şerh ve takyidatların terkini işlemi kamu düzeniyle ilgili olduğundan açılacak davada hakemlerin görevli olduğu kabul edilemez. Ancak genel mahkemelerde dava açlabilir. O halde hakem tayini isteminin reddi yerine görevli olduğunu kabul eder biçimde atama yapılması usul ve yasaya aykırıdır. Kararın bu nedenlerle bozulması gerekir. SONUÇ: Yukarıda açıklanan nedenlerle davalının temyiz isteminin kabulü ile mahkeme kararının BOZULMASINA, ödediği temyiz peşin harcının istek halinde temyiz eden davalıya geri verilmesine, 13.10.2004 gününde oybirliğiyle karar verildi" (Erişim: 04.03.2021, https://www.kararara.com/yargitay/yhdk8/yrgtyk17398.htm).

37 Yargitay 15. HD. T. 31.5.1979, E. 1979/1195, K. 1979/1330, Yargitay Kararları Dergisi, S. 1981/3, s. 342-343. Ayrica bkz. Akınc1, s. 354 vd. Yargitay 19 HD. 25.10.2018, E. 2016/19635, K. 2018/5253, "Taraflar arasındaki hakem kararının iptali davasının yapılan yargılaması sonunda ilamda yazılı nedenlerden dolayı davanın reddine yönelik olarak verilen hükmün süresi içinde davacı vekilince temyiz edilmesi üzerine dosya incelendi, gereği konuşulup düşünüldü. KARAR: Davacı vekili, davacı ile davalı arasında gayrimenkul satış vaadi sözleşmesi akdedildiğini, davalının sözleşmede belirtilen süre içerisinde gayrimenkulün fiilen teslim edilmediği gerekçesiyle tahkim yoluna başvurduğunu, yapılan yargılamada hakem kurulunun davalı lehine kira kaybı nedeniyle tazminata hükmettiğini, ancak hakem kurulunun inşaatın iskan 
bakıldığında, Yargıtay’n kira sözleşmesinde kiracının zayıf konumda olması veyahut kamu düzenini korumak gayesiyle muayyen borç ilişkileri alanında tahkime gidilmesini engellediği görülmektedir ${ }^{38}$. Yargıtay, zayıf konumda olan kiracının korunması nedeniyle bu tür uyuşmazlıkların mahkeme yoluyla çözüme bağlanması gerektiği düşüncesindedir ${ }^{39}$. Akıncı kira sözleşmelerinin tahkime elverişli olduğu kanaatindedir; zira burada MTK’nın ilgili maddesinin aksinden hareket edildiğini yani kira sözleşmelerinin taşınmazın aynına dair olmadığı noktasının üzerinde durulduğunda bu hususta bir engel olmadığını belirtmektedir ${ }^{40}$. Yazar, Türkiye’de bulunan bir taşınmazla ilgili olup, taşınmazın aynına dair olmayan ihtilaflarda (örneğin bir taşınmazın inşası ile ilgili eser sözleşmesinden doğan bir uyuşmazlık halinde) tahkime gidilebileceğini ifade etmektedir ${ }^{41}$. Özkan/ Tütüncübaşı da kira sözleşmesinin taşınmazın aynına ilişkin olmamasından hareketle, bu sözleşme tipi için tahkim yoluna başvurulabileceği görüşündedir ${ }^{42}$. Ancak yazarlar, tapu iptal ve tescil davalarının kamu düzenini ilgilendiren davalar olmasının üzerinde durarak, bu davaları tahkime

ruhsatının alınmasının mücbir sebepler nedeniyle gecikmesi yönünde inceleme yapmadığını, sözleşme ile vaat edilen 24 ay içerisinde gayrimenkullerin fiilen teslim edildiğini ve ... yerlerinin kullanılmaya başlandığını, bu nedenle kira alacağ kaybının olmasının mümkün olmadığını ileri sürerek hakem kararının iptalini talep ve dava etmiştir. Davalı vekili, hakem kararına konu olan uyuşmazlığın taşınmazın geç teslimi sebebiyle talep edilen kira kaybı alacağına ilişkin olduğunu, bu uyuşmazlığın Türk hukukuna göre tahkime elverişli olduğunu ve verilen kararın kamu düzenine uygun olduğunu, kanunda sınırlı şekilde sayılan iptal şartlarının gerçekleşmediğini, mahkemenin uyuşmazlığı esastan inceleyemeyeceğini, ayrıca davacı şirketin olağan genel kurul toplantılarında inşaatların kendi kusurlarından geciktiğini kabul ederek gecikme tazminatı ödemeyi açıkça kabul ettiğini belirterek davanın reddini istemiştir. Mahkemece, tüm dosya kapsamına göre, hakem heyetinin seçimine ilişkin iptal sebebine dayanılmadığı, kararın tahkim süresi içerisinde verildiği, geç teslime dayalı kira alacağı istemine konu olan uyuşmazlıkta kira alacağı belirlenmesinin sözleşmeye uygun olmadığı ve mücbir sebep olgularının dikkate alınmadığı yönündeki iddianın sınırlı sayma yöntemi ile iptal sebeplerini düzenleyen HMK’nın 439. maddesi kapsamına uymadığı, hakem kararının kamu düzenine de aykırılık oluşturmadığı gerekçesiyle davanın reddine karar verilmiş, hüküm davacı vekilince temyiz edilmiştir. Dava, hakem kararına yönelik iptal davasıdır. Mahkemece, HMK 439. maddesi uyarınca hakem kararının iptaline ilişkin sebeplerin bulunmadığı belirtilerek davanın reddine karar verilmiştir. Taraflar arasındaki uyuşmazlık gayrimenkul satış vaadi ve alııı kredisi temini sözleşmesinden kaynaklanmaktadır. Sözleşmenin 21.maddesinde taraflar arasındaki uyuşmazlıkların çözümü için tahkim şartı öngörülmüş ise de tapuda kayıtlı bir taşınmazın satış vaadi sözleşmesinin geçerli olabilmesi için noterde (resmi şekilde) yapılması gerektiğinden, somut olayda da söz konusu sözleşme noterde yapılmadığından geçersizdir. Taraflar arasındaki sözleşme tarihi 02.04.2009 olup 818 sayılı BK’nun yürürlükte olduğu dönemde imzalanmıştır. 6098 sayılı TBK 01.07.2012 tarihinde yürürlüğe girmiştir. 6101 sayılı TBK’nun Yürürlüğü ve Uygulama Şekli Hakkındaki Kanunun 2. maddesinde, TBK’nun kamu düzenine ve genel ahlaka ilişkin kurallarının gerçekleştikleri tarihe bakılmaksızın bütün fiil ve işlemlere uygulanacağı, 7. maddesinde ise derdest davalara da uygulanacağı hükme bağlanmışsa da bu düzenlemeler kamu düzenine ve genel ahlaka yönelik kurallara ilişkin olup somut olayda uygulama yeri bulunmamaktadır. Bu nedenle TBK’nun 412/4. maddesindeki "tahkim sözleşmesine karşı asıl sözleşmenin geçerli olmadığı itirazında bulunulamaz" hükmü somut olayda uygulanamaz. Bu durumda gayrimenkul satış vaadi sözleşmesi resmi şekilde yapılmadığından geçersiz olup, sözleşmedeki tahkim şartının da geçersiz olduğu gözetilmeden mahkemece yazılı şekilde hüküm kurulması doğru görülmemiştir. SONUÇ: Yukarıda açılanan nedenlerle hükmün BOZULMASINA, peşin harcın istek halinde temyiz eden davacıya iadesine, 25/10/2018 gününde oybirliğiyle karar verildi" (Erişim: 04.03.2021, www.legalbank.net).

38 Şanl, Ticari Akitler, s. 315. Ayrıca bkz. Akınc1, s. 357 dn. 481, 482 ve 483 ’te yer alan Yargitay kararları.

39 Yargitay 4. HD., T. 11.11.1965, E. 1965/7792 K.1965/5764; Yargitay 4. HD. 13.9.1965, E.1965/6722, K. 1965/4090; Yargitay 6. HD. 10.7.1970, E. 1970/3032, K. 1970/3170; Yargitay 4. HD. 05.11.1966 E. 1966/9110, K. 1966/9554; kararlar için bkz. Akınc1, s. 357, dn. 481 vd.

40 Akıncı, s. 356. Aynı yönde bkz. Ömeroğlu, Ekin, Taşınmazların Kiralanmasına İlişkin Sözleşmelerin Uygulanacak Hukuk, Milletlerarası Yetki ve Milletlerarası Tahkim Bakımından Türk Hukukundaki Yeri, TBB Dergisi 2016 (127), s. 392.

41 Akınc1, s. 356.

42 Özkan/Tütüncübaşı, s. 243. 
elverişli görmemektedir ${ }^{43}$. Şanlı/Esen/Ataman Figanmeşe, Türk hukukunda tahkime elverişliliğin kriteri olarak tarafların serbestçe tasarruf edebilmesi prensibi belirlenmişken, taşınmazın aynından doğan uyuşmazlıkların tahkime elverişli sayılmamasının çelişkili olduğunu; bu tür uyuşmazlıklarda da tarafların karşılıklı anlaşarak sulh olabileceğini, birbirlerini ibra edebileceğini işaret etmektedir ${ }^{44}$.

Ömeroğlu, ayni hakka ilişkin olmayan kira bedelinin tespiti gibi hususlarda tahkime elverişsizlik sonucuna varılmasını MTK md. 1'e aykırılık olarak değerlendirmektedir ${ }^{45}$. Yargıtay'ın taşınmaz kirasında kira bedel tespitine dair ihtilafın tahkime elverişli olmadığ 1 yönündeki kararında ${ }^{46}$, tarafların kira bedelini ancak belirli sınırlamalar dahilinde kendi rızalarıyla kararlaştırmalarının mümkün olduğu, bu yönüyle kira bedel tespitinin kamu düzeninden sayıldı̆̆ 1 yönünde karar verilmiştir. Yılmaz/Çavuşoğlu, kira bedelinin tespitine dair uyuşmazlıklarda Yargıtay'ın tahkime gidilemeyeceğine karar vermesini taşınmazın aynına dair olmayan ve kanun metnini aşan bir uygulama olarak kabul edip eleştirmektedir ${ }^{47}$. Yargıtay, iki tarafın da tacir olduğu bir tahliye davasında ise, taraflar arasındaki uyuşmazlığın tahkime elverişli olduğu yönünde karar vermiştir ${ }^{48}$. Bu karardan, Yargitay’ın tacir ve tacir olmayan ayrımına önem verdiği anlaşılmaktadır. Ömeroğlu, Yargıtay kararlarını tahkime elverişlilik konusunda kamu düzeninin sınır teşkil etmemesi sebebiyle eleştirmekte; hakem yargılamasında kira bedelindeki sınırlamalara uygun bir artış oranına hükmedilmesi halinde kamu düzenine aykırılı̆̆ın ortadan kalkabileceğini ifade etmektedir ${ }^{49}$. Bununla birlikte, kira bedelindeki artışın Türk hukukunda emredici hükümlerle düzenlenmiş, olmasının tahkime elverişlilik açısından belirleyicilik getirmediği düşüncesi de mevcuttur ${ }^{50}$. Takavut, taşınmazların kira tespiti ve tahliyesi için Yargıtay kararlarında ve uygulamada genel bir anlayışın kabul edildiğini fakat konut ve iş yeri ayrımı yapılarak farklı bir değerlendirilme olması gerektiğini

43 Özkan/Tütüncübaşı, s. 243.

44 Şanlı/Esen/Ataman Figanmeşe, s. 771, dn. 628.

45 Ömeroğlu, s. 393.

46 Yargıtay 3. Hukuk Dairesi, T. 2.12.2004, 13018/13409 (Erişim: 04.03.2021, www.kazanci.com).

47 Yılmaz, Süleyman/Çavuşoğlu, Gökçe Filiz, Türk Hukukunda Tahkime Elverișlilik Kavramı ve Taşınmazın Aynına İlişkin Uyuşmazlıkların Tahkimde Görülmesi, İnÜHFD (10/2), 2019, s. 602; Ömeroğlu, s. 393.

48 Yargitay 19. HD. 16.12.2004, E.2004/5413, K.2004/12656 (Erişim: 04.03.2021, www.legalbank.net); “Davacı D. A.Ş. ile davalı A. Dış Tic. A.Ş. aralarındaki hakem tayini davası hakkında hakem heyetince verilen 28.1.2003 gün ve 1503-7 sayılı kararın davalı vekili tarafından temyiz edilmesi ve dosyanın İstanbul 2. Asliye Ticaret Mahkemesince Dairemize intikal ettirilmesi üzerine dosya dosya incelendi, gereği konuşuldu. KARAR: Davacı vekili, taraflar arasında imzalanan 25.6.2001 tarihli sözleşmenin 8.maddesinde sözleşmenin uygulanmasından doğabilecek ihtilafların hakemde görüleceğinin hükme bağlandığını, ihtilaf çıkması üzerine müvekkilinin ve davalının hakemlerini seçtiğini, üçüncü hakem üzerine de anlaşamadıklarını ileri sürerek üçüncü hakem tayinine karar verilmesini talep ve dava etmiştir. Davalı vekili cevabında, taraflar arasındaki sözleşmenin sona ermesi nedeniyle hakeme gidilemeyeceğini, uyuşmazlığın tahliyeden kaynaklandığını, tahliye davasında tahkim yoluna başvuramayacağını belirterek talebinin reddini istemiştir. Mahkemece, sözleşmenin feshinin haklı olup olmadığının ve oluşan zararın ne miktar olduğunun belirlenmesi yönündeki ihtilafın hakemde çözüleceği, üçüncü hakemin mahkemece belirleneceği gerekçesiyle 25.6.2001 tarihli sözleşme uyarınca üçüncü hakem olarak B'un atanmasına karar verilmiş, karar davalı vekilince temyiz edilmiştir. SONUÇ: Dosyadaki yazılara kararın dayandığı delillerle gerektirici sebeplere, delillerin takdirinde bir isabetsizlik bulunmamasına göre, davalı vekilinin yerinde görülmeyen bütün temyiz itirazlarının reddiyle usul ve kanuna uygun bulunan hükmün ONANMASINA, aşağıda yazılı onama harcının temyiz edenden alınmasına, 16.12.2004 gününde oybirliği ile karar verildi".

Ömeroğlu, s. 393.

50 Huysal, s. 132-134; Ömeroğlu, s. 393. 
ifade etmektedir ${ }^{51}$. Yazar, zayıf tarafı koruma amaçlı getirilen düzenlemelerde hangi tarafın tahkime gittiğine bakılması gerektiğini, eğer zayıf taraf tahkime gidiyorsa ihtilafın tahkime elverişli kabul edilmesi gerektiğini, seçilecek hukuklardan gelen korumalar söz konusuyken tahkim yargılamasına izin verilmemesinin anlam ifade etmediğini izah etmektedir ${ }^{52}$. Albayrak Ceylan, zayıf tarafın tahkim yoluna başvurduğu hallerin istisna kılınarak kira sözleşmelerinde tahkim şartlarının geçersiz kabul edilmesini; bu alanları koruyan kanun düzenlemelerinin amacına uygun olarak ilgili hususlarda tahkime elverişsizliğin kabul edilmesi gerektiğini ileri sürmektedir ${ }^{53}$.

Doktrindeki görüşler ışı̆̆ında kira sözleşmesinin genellikle tahkime elverişlilik başlı̆̆1 alında incelendiği görülmektedir. Bu çatı altında inceleme yapan yazarlar, kira sözleşmesine dair Yargitay’ı̀n zayıf tarafı koruma düşüncesinden yola çıtığını belirten, sosyal ve ekonomik gerekçelerle tahkime elverişsizlik ilkesine vurgu yapan genel bir kanaat bildirmektedir ${ }^{54}$.

\section{DEĞERLENDIRMELER}

Kira sözleşmelerinden doğan uyuşmazlıkların tahkime elverişliliği meselesinde ilk olarak taşınmazın Türkiyede bulunup bulunmadığı ayrımı üzerinden bir değerlendirme yapmak gerekir. MTK md. 1'den yola çıktığımızda, taşınmazın Türkiyede bulunan bir taşınmaz olduğu anlaşılmaktadır; bu durumda yabancı ülkedeki bir taşınmaz madde kapsamına girmemektedir. Bu konuda doktrinde bir tartışma bulunmamaktadır. MTK md. 1'in yabancı ülkelerde yer alan taşınmazlar üzerindeki ayni haklara dair uyuşmazlıkların MTK kapsamında tahkime elverişsiz kabul edilmesi, maddenin lafzının aşılmasına neden olacaktır. Maddenin konuluş amacına baktığımızda, Türkiyedeki taşınmazları dikkate aldığı çok açıktır. Bu nedenle, lafzın aşılması yoluyla taşınmazlara dair evrenselleştirilmeye gidilmemesi gerektiğini düşünmekteyiz.

Hukuk devletinde temel hak ve özgürlükler insan haklarına dayanmakta, insan hakları ise Anayasa ve yasalarca bireylere tanınan temel hak ve özgürlüklerin de ötesinde arzulanan ve ulaşılması gereken hak ve özgürlükleri ifade etmektedir ${ }^{55}$. Eşitlik ilkesiyle tanımlanan özgürlük sadece kişilere hukuk normlarıyla tanınan haklar vasıtasıyla anlam kazanamaz ${ }^{56}$. Locardaire'in "zengin ve yoksul karşı karşıya kaldığında özgürlük ezer, yasa ise kurtarıcı olur” sözünden hareketle bir yasanın zayıf taraftakini kurtarabilmesi için sosyal devlet ilkesinin tam anlamıyla benimsenmiş olması gerekmektedir ${ }^{57}$. Kira sözleşmelerine dair ihtilaflarda Yargıtay’ın zayıf tarafı koruma saikiyle verdiği tahkime elverişsizlik kararlarını bahsedilen sosyal devlet ilkesi kapsamında anlamaktayız. Sosyal devlet ve hukuk devleti ilkeleri gereğince barınma en temel haklardan biridir; bu kapsamda kişilerin hayatlarını sürdürmek için barındıkları yerlere ait kira sözleşmelerinin barınma hakkı

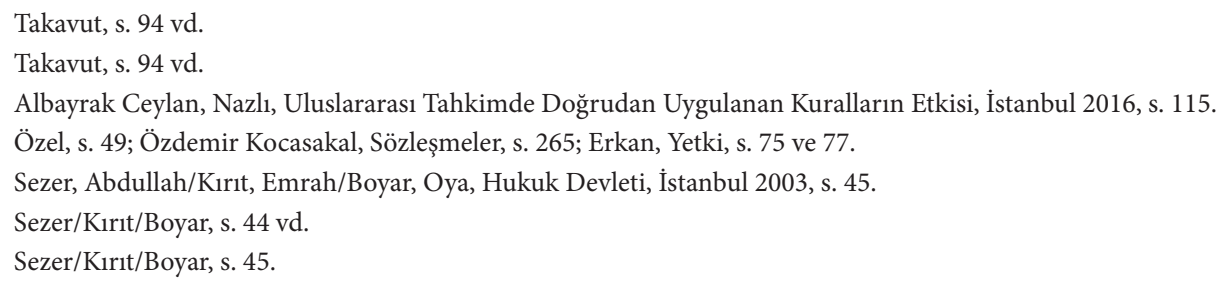


temel alınarak değerlendirilmesi gerektiğini düşünmekteyiz. Bu nedenle, doktrinde ve Yargıtay kararında yer alan tacirler arasındaki ve tacir olmayanlar şeklinde yapılan ayrıma katılmamaktayız. Zira burada taraflardan ziyade taşınmazın kullanım amacı önem taşımaktadır. Yabancı ülkelerde sıklıkla gördüğümüz üzere, konut olarak kullanılan taşınmazı kiraya veren bir şirket olabilir. Bu halde, taşınmazın Alman hukukunda kabul edilen anlayış benimsenerek ne niyetle kullanıldığına, diğer bir ifadeyle kullanım amacına bakılması gerektiği kanaatindeyiz. Alman hukukunda konut kira sözleşmelerinin tahkime elverişsiz olduğu kabul edilmektedir $(\mathrm{ZPO} \$ 1030)^{58}$. Alman medeni usul hukukundaki düzenlemeye göre, konut kirasından kaynaklanan ihtilaflarda tahkime gidilemez; şayet gidilmişse tahkime elverişsizlik olduğu kabul edilir. Kiraya verene karşı sosyal koruması olmayan konut kiracısı devletin hukuk vasıtalarıyla korunmalıdır ${ }^{59}$; aksine bir düzenleme vatandaşın sosyal korunması kavramının "kağıttan bir kaplana" benzetilmesine yol açacaktır ${ }^{60}$. Alman Medeni Usul Kanunu’ndaki bu düzenlemenin çekirdeği devlet kontrolünün engelleyici fonksiyonunun kullanılmasıdır ${ }^{61}$. Kanun'da yer alan konut kavramının tanımı için Alman Medeni Kanunu’ndan hareket edilmektedir; kira sözleşmesine konu olan taşınmazın düzenli olarak oturulan, kiracının hayat ilişkisini devam ettirdiği ve yaşamak amacıyla kiralanan bir yer olması aranır ${ }^{62}$. Alman Usul Kanunu bu noktada kira sözleşmesinin taraflarına değil, sözleşmesinin konusuna odaklanmaktadır; bu nedenle tahkime elverişlilikte konut tanımı önem taşımaktadır ${ }^{63}$. Bu noktada şu noktayı aydınlatmak gerekir: Tahkime elverişsiz kabul edilen konut için coğrafi sınırlama getirilmiştir; sadece Almanya'da bulunan konutlara dair yapılan kira sözleşmeleri objektif anlamda tahkime elverişsiz ${ }^{64}$ sayılmaktadır ${ }^{65}$. Alman doktrini, konut olarak kullanılan yerlerle ilgili kira sözleşmelerinin tahkime elverişsiz olması hususunda bir tartışma içerisinde değildir; aksine kiracının devlet mahkemelerinin denetiminden yoksun kalması halinde, kiraladığı konutu kaybetme riskinin oluşacağını; konutun bulunduğu yer mahkemesinin bu davalara bakması ve ihtilafı denetlemesi gerektiğini, başta tahliye davası olmak üzere bu bakış açısının taraflar arasında konut kirası sözleşmesinden doğan diğer ihtilaflarda da geçerli kabul edildiğini izah etmektedirler ${ }^{66}$. Geçerli bir konut kirası sözleşmesinin tarafı olan kiracının, tahkim yargılamasında baskı altına alınacağı da ileri sürülmektedir ${ }^{67}$.

58 Rauscher, Thomas, in: Münchener Kommentar zur ZPO, München 2020, Rn. 72.

59 Münch, Rn. 3

60 Münch, Rn. 25.

61 Münch, Rn. 2.

62 Wendt, Stephan, Die einstweilige Räumungsverfügung des §940a Abs. 2 ZPO, Tübingen 2015, s. 203; Münch, Rn. 30.

63 Münch, Rn. 30; von Bary, Christiane, Schiedsfähigkeit und Bindungswirkung bei einseitigen Schiedsanordnungen im Erbrecht unter Berücksichtigung der internationalen Perspektive, ZEV 2019, s. 322.

64 Tahliye davasının tahkime elverişsizliği ile ilgili olarak bkz. AG Münster Urt. v.23.07.2008, 49 C 5632/07 (Erişim: 04.03.2021,

https://www.jusmeum.de/urteil/ag_muenster/6cb7bcf99aa36828353b985cc3df4bfd80253eec6ba3e15fbbc15bfd9ad3b273).

65 Vincent, s. 66.

66 Vincent, s. 66 vd.; Münch, Rn. 25; von Bary, s. 322 vd.

67 Vincent, s. 67. İsviçre Hukuku’na baktığımızda, İsviçre Mahkemesi’nin 2015 yılında verdiği karar uyarınca, kira uyuşmazlıklarında tahkim yargılamasına gidilemez; zira bu uyuşmazlıklar tahkime elverişli değildir. Kararda, konut kirası uyuşmazlıklarında kiracının korunmasının gerektiğini belirtilerek, dava konusu on odalı lüks villa tipi konutların da aynı kapsamda değerlendirildiği ifade edilmektedir; BGE 141 III 201/2015; (Erişim: 04.03.2021,

http://relevancy.bger.ch/php/clir/http/index.php?highlight_docid=atf\%3A\%2F\%2F141-III-201\%3Ade\&lang=de\&type=show_ document) 
Türk yargılamasında kira sözleşmesinin tahkime elverişliliği üç farklı yönden değerlendirilebilir. Yargıtay; tahliye ${ }^{68}$, kira bedelinin tespiti ${ }^{69}$ ve kira alacağının tahsiline ${ }^{70}$ dair uyuşmazlıklarda ayrım yapmaktadır. Alacağa dair uyuşmazlıklarda tahkime elverişliliğe olumlu bakılırken, kira bedelinin

68 Yargitay 6. HD. 10.07.1970, E. 1970/3170, K. 1970/3032; İBD 1971/I-II, s. 144 vd.

69 Yargitay 3. HD. 02.12.2004, E. 2004/13018, K. 2004/13409, (Erişim: 04.03.2021, www.legalbank.net): “ÖZETİ: Kamu düzenini ilgilendiren kira tesbit uyuşmazlıklarının çözümü hakkındaki tahkim şartı HUMK.nun 518. maddesi hükmü gereğince geçersiz olacağından dava konusu kira uyuşmazlığının hakem heyeti tarafından görülmesi doğru değildir. Dava dilekçesinde taşınmazın yıllık kira parasının net 300.000.000 liradan az olmamak üzere hakem heyeti tarafından tesbiti masraflarla birlikte davalı taraftan tahsili istenilmiştir. Mahkemece davanın kısmen kabulü, kısmen reddi cihetine gidilmiş, hüküm davacı vekili tarafından temyiz edilmiştir. Temyiz isteminin süresi içinde olduğu anlaşıldıktan sonra dosyadaki bütün kağıtlar okunup gereği düşünüldü: Davacı vekili dilekçesinde, taşınmazın yıllık kirasının net 300.000.000 TL’den az olmamak üzere hakem heyeti tarafından tesbitine karar verilmesini talep ve dava etmiştir. Hakem heyeti tarafından yıllık kiranın120.000.000.000 TL olarak tesbitine karar verilmiştir. HUMK.nun 518. maddesi gereğince, tahkim sözleşmesi yalnız tarafların arzularına tabi olan uyuşmazlıklar hakkında mümkündür. Bundan maksat, tarafların konusu üzerinde serbestçe tasarruf yetkilerinin bulunduğu uyuşmazlıklardır. Taraflar, aralarındaki uyuşmazlığı gidermek için serbestçe anlaşma yapabiliyorlar ve bu anlaşma mahkemenin kararına gerek olmaksızın geçerli ise, o uyuşmazlık hakkında tahkim sözleşmesi (ya da tahkim şartı) yapılabilir. İki tarafın arzusuna tabi olmayan ...tahkim cereyan etmez.Yani tarafların dava konusu üzerinde serbestçe tasarruf edemeyecekleri hallerde tahkim caiz değildir. Yargıtay’n yerleşik uygulamalarına göre, kira bedelinin tesbiti davalarında tahkim yoluna başvurulamaz. Kira tesbiti hususu kamu düzenini ilgilendirdiği için, tarafların serbest iradeleri ile kira parasını karşılaştırmaları ancak belli ölçüler ve sınırlar dahilinde mümkündür. Dolayısıyla bu hususta tarafların tasarruf yetkileri sınırsız değildir. Kaldı ki kiracı, kiralayanın talep ettiği kira bedelini de ödemek zorunda değildir. O halde kamu düzenini ilgilendiren kira tesbit uyuşmazlıklarının çözümü hakkındaki tahkim şartı HUMK.nun 518. maddesi hükmü gereğince geçersiz olacağından dava konusu kira uyuşmazlığının hakem heyeti tarafından görülmesi doğru değildir. SONUÇ: Bu itibarla yukarıda açıklanan esaslar gözönünde tutulmaksızın yazılı şekilde hüküm tesisi isabetsiz, temyiz itirazları bu nedenlerle yerinde olduğundan kabulü ile hükmün HUMK.nun 428 . maddesi gereğince BOZULMASINA ve peşin alınan temyiz harcının istek halinde temyiz edene iadesine, 2.12.2004 tarihinde oybirliğiyle karar verildi".

70 Yargıtay 6. HD. 30.01.2013, E. 2012/9581, K. 2013/1334, "ÖZETİ: Gerek davacının dayandığı 01.08.2005 tarihli sözleşmenin 11. maddesinde, gerekse de davalının dayandığı 01.10 .2005 başlangıç tarihli kira sözleşmesinin 7. maddesinde ihtilaf halinde Ticaret Odası’ndan ve Esnaf Odası̉ndan 2'şer kişinin hakemliğine başvurulacağı kararlaştırılmıştır. Davalı tarafından yasal süresi içerisinde verilen cevap dilekçesinde, taraflar arasındaki ihtilaflarda hakeme başvurulacağı hususunu bildirerek itirazda bulunmuştur. Öncelikle kira sözleşmesindeki tahkime dair hüküm ve davalının bu yöndeki itirazının 1086 Sayılı HMUK'nun 516 vd. maddeleri ve 6100 Saylı HMK'nun 412 vd. maddeleri çerçevesinde değerlendirilmesi gerekirken, davalının bu yöndeki ilk itirazları değerlendirilmeden davanın esası hakkında karar verilmesi doğru değildir. Mahalli mahkemesinden verilmiş bulunan alacak davasına dair karar; davalı ve davacı tarafından süresi içinde temyiz edilmiş olmakla, dosyadaki bütün kağıtlar okunup gereği görüşülüp düşünüldü: KARAR: Dava, kira alacağının tahsili istemine ilişkindir. Mahkemece, davanın kısmen kabulüne karar verilmiş, hüküm davalı ve davacı tarafından temyiz edilmiştir. Davacı, dava dilekçesinde 01.08.2005 başlangıç tarihli kira sözleşmesine istinaden kira alacağı talebinde bulunmuştur. Davalı yasal süresi içerisinde verdiği cevap dilekçesinde, taraflar arasında geçerli olan sözleşmenin davacının dayandığı sözleşme değil, 01.10.2005 tarihli kira sözleşmesi olduğunu, kira borcunun bulunmadığını, ayrıca kira sözleşmesinde, Ticaret Odası̉nın hakemliğinin kararlaştırıldığını, davacının bu hususu nazara almadığını belirterek davanın reddini savunmuştur. Gerek davacının dayandığı 01.08.2005 tarihli sözleşmenin 11 . maddesinde, gerekse de davalının dayandığı 01.10.2005 başlangıç tarihli kira sözleşmesinin 7. maddesinde ihtilaf halinde Ticaret Odası’ndan ve Esnaf Odası’ndan 2'șer kişinin hakemliğine başvurulacağı kararlaştırılmıştır. Davalı tarafından yasal süresi içerisinde verilen cevap dilekçesinde, taraflar arasındaki ihtilaflarda hakeme başvurulacağı hususunu bildirerek itirazda bulunmuștur. Öncelikle kira sözleșmesindeki tahkime dair hüküm ve davalının bu yöndeki itirazının 1086 Sayılı HMUK’nun 516 vd. maddeleri ve 6100 Sayılı HMK’nun 412 vd. maddeleri çerçevesinde değerlendirilmesi gerekirken, davalının bu yöndeki ilk itirazları değerlendirilmeden davanın esası hakkında karar verilmesi doğru değildir. Hüküm bu sebeple bozulmalıdır. SONUÇ: Yukarıda yazılı sebeplerle davalının temyiz itirazlarının kabulüyle 6100 Sayılı HMK'ya 6217 Sayllı Kanunla eklenen geçici 3. madde hükmü gözetilerek HUMK’nun 428. maddesi uyarınca hükmün BOZULMASINA, bozma nedenine göre davacı ve davalının sair temyiz itirazlarının şimdilik incelenmesine yer olmadığına, istenmesi halinde peşin alınan temyiz harcının temyiz edenlere iadesine, 30.01.2013 tarihinde oybirliği ile karar verildi” (Erişim: 04.03.2021, www.legalbank.net). 
tespiti ve tahliye davalarında tahkim yoluna başvurmanın mümkün olmadığ görülmektedir. Buradan yola çıkılarak kira alacağına dair ihtilafların tahkime elverişliliği düşünülebilir mi? Bu hususta, yukarıda Alman hukukunda savunulan düşünceye katılıyoruz. Konut için yapılan kira sözleşmelerini bir bütün olarak değerlendiriyor ve bu hususta tahkime elverişsizlik bulunduğunu düşünüyoruz. İş yerleri için yapılan kira sözleşmelerinin ise tahkime elverişli olduğu kanaatindeyiz.

\section{SONUÇ}

MTK md. 15/A/2/a uyarınca hakem veya hakem kurulu kararına konu uyuşmazlık Türk hukukuna göre tahkime elverişli olmadığı takdirde kararının iptal edilmesi ihtimali gündeme gelebileceğinden, kira sözleşmelerinden doğan uyuşmazlıkların tahkime elverişliliği önem arz eden bir meseledir. Çalışmamızda MTK kapsamında kira sözleşmelerinin tahkime elverişlilik durumu incelenmiştir. Kanun koyucu MTK düzenlemesinde taşımazlar üzerindeki ayni hakları tahkime elverişsiz kabul ederken elbette ki kira sözleşmelerini kastetmemektedir; bu sözleşme tipinin taşınmazın aynına dair olmadığı bilinmektedir. Ancak burada daha farklı bir bakış açısı söz konusu olabilir.

Beslenme ve barınma insanın en temel ihtiyaçlarından biridir; insanların hayatlarının her anında hissettikleri bu iki ihtiyacın asgari seviyede de olsa giderilmesi; hayatta kalabilmelerinin, sağlıklı bir hayat kurabilmenin koşuludur ${ }^{71}$. Ülkemizde barınma sorunu gelir düzensizlikleri, nüfus artışı, hızlı kentleşme süreçleri gibi nedenlerle artış göstermektedir ${ }^{72}$. Kira sözleşmesinin tarafları olan kiraya veren ve kiracı tahkim yargılamasında aralarındaki ihtilafı neticelendirmeye çalışacaktır. Taraflardan birinin zayıf konumda olduğu sözleşmelerden biri kabul ettiğimiz kira sözleşmesinde, tahkime elverişliliğin mukayeseli hukuktaki anlayışla konut üzerinden tespit edilmesi gerektiğini düşünmekteyiz. Buradan hareketle, kiracının barındığı, düzenli olarak yaşadığı ve hayatını idame ettirdiği konutla ilgili ihtilafın MTK kapsamında tahkime elverişli olmadığı; iş yeri olarak kullanılan yerlerde kira sözleşmesinden doğan uyuşmazlıklarda ise tahkime elverişlilik olduğu kanaatindeyiz. Şayet kira sözleşmesi tahkime elverişlilik kapsamında değerlendirilemeyecekse, MTK md. 15/A/2/a uyarınca hakem veya hakem kurulu kararına konu uyuşmazlığın Türk hukukuna göre tahkime elverişli olmadığı belirlenerek hakem kararının iptal edilmesi yoluna gidileceğinden bu hususun önem arz ettiğini düşünmekteyiz.

\section{KAYNAKLAR}

Acar, Faruk, Kira Hukuku Şerhi, (TBK m. 299-321), Yenilenmiş, ve Genişletilmiş, 2. Baskı, İstanbul 2015.

Akartepe, Alpaslan, Türk Borçlar Kanunu’nun 315. Maddesi Çerçevesinde Kiracının Kira Bedelini Ödemede Temerrüdü ve Hukuki Sonuçları, MÜHF - HAD, Prof. Dr. Cevdet Yavuz’a Armağan Özel Sayısı, C: 22, S: 2016/3.

71 Akalın, Mehmet, Kiralık Sosyal Konutlar: Türkiyede Barınma Sorununun Çözümü İçin Yeni Bir Yöntem, ÇAKÜ Sosyal Bilimler Enstitüsü Dergisi/ Journal of Institute of Social Sciences Cilt/Volume: 9, Say1/Number:1, (Nisan/April 2018), s. 88.

72 Akalın, s. 89. 
Akalın, Mehmet, Kiralık Sosyal Konutlar: Türkiye’de Barınma Sorununun Çözümü İçin Yeni Bir Yöntem, ÇAKÜ Sosyal Bilimler Enstitüsü Dergisi/ Journal of Institute of Social Sciences Cilt/Volume: 9, Sayı/Number:1, (Nisan/April 2018).

Akınc1, Ziya, Milletlerarası Tahkim, İstanbul 2020.

Akıncı, Ziya, Milletlerarası Ticari Uyuşmazlıkların Alternatif Çözüm Yolları, BATİDER 18/4, 1996, (kısaltma: BATIDER).

Akyiğit, Ercan, 6098 sayılı Türk Borçlar Kanunu’nda Kira Sözleşmesi, İstanbul 2012.

Alangoya, Yavuz, Medeni Usul Hukukumuzda Tahkimin Niteliği ve Denetlenmesi, İstanbul 1973.

Alangoya, Yavuz/Yıldırım, M.Kâmil/Deren Yıldırım, Nevhis, Medeni Usul Hukuku Esasları İstanbul 2009.

Albayrak Ceylan, Nazlı, Uluslararası Tahkimde Doğrudan Uygulanan Kuralların Etkisi, İstanbul 2016.

Ansay, Sabri Şakir, Hukuk Yargılama Usulleri, Ankara Hukuk Fakültesi Yayınları, Ankara 1960.

Aral, Fahrettin/Ayrancı, Hasan, Borçlar Hukuku Özel Borç İlişkileri, Ankara 2015.

Aybay, Rona/Dardağan, Esra, Uluslararası Düzeyde Yasaların Çatışması, İstanbul 2008.

Çelikel, Aysel/Erdem, B. Bahadır, Milletlerarası Özel Hukuk, İstanbul 2020.

Doğan, Vahit, Tahkime Elverişlilik Bağlamında Yabancı Unsur, Ed. Doğan, Vahit/Yılmaz, Alper Çağrı/İzmirli, Lale Ayhan, Milletlerarası Özel Hukukta Güncel Meseleler Sempozyumu, Antalya Bilim Üniversitesi Hukuk Fakültesi, Ankara 2019.

Doğan, Vahit, Milletlerarası Özel Hukuk, Ankara 2020.

Eren, Fikret, Borçlar Hukuku Özel Hükümler, Ankara 2017.

Erkan, Mustafa, Tahkim Şartının Ayrılabilirligi Prensibinin Asıl Sözleşmenin Yokluğu Durumunda Değerlendirilmesi, Gazi Üniversitesi Hukuk Fakültesi Dergisi C. XVII, 2013/ 1-2.

Erkan, Mustafa, Milletlerarası Tahkimde Yetki Sorunları, Ankara 2013 (kısaltma: Yetki).

Ersen Perçin, Gizem, MTK Tahkiminde İptal Davalarına İlişkin Bir Değerlendirme, PPIL 40/2, (Cemal Şanlı Armağanı), 2020.

Esen, Emre, Uluslararası Tahkime Tabi Bir Uyuşmazlığın Devlet Mahkemelerine Götürülmesi Halinde Tahkim Anlaşmasının Geçerliliğine İliş̧kin İtirazların İncelenmesi ve Kompetenz-Kompetenz Prensibi, Galatasaray Üniversitesi Hukuk Fakültesi Dergisi (Prof. Dr. Ata Sakmar’a Armağan), 2011.

Giray, Faruk Kerem, Milletlerarası Tahkimde Gizlilik, Uluslararası Ticaret ve Tahkim Hukuku Dergisi, S. 2015/2. Güngör, Gülin, Türk Milletlerarası Özel Hukuku, Ankara 2021.

Gökyayla, Emre, Konut ve Çatılı İş yeri Kiralarına İlişkin Hükümlerin Uygulama Alanı (TBK md. 339), Prof. Dr. Aydın Zevkliler’e Armağan, Cilt: 2, İzmir 2013.

Gümüş, M. Alper, 6098 Sayılı Borçlar Kanununa Göre Kira Sözleşmesi, İstanbul 2011.

Hamann, Hartmut/Lennarz, Thomas, Schiedsverfahren oder staatliche Gerichtsverfahren - Was ist besser?, Stuttgart JA, 2012.

Huysal, Burak, Milletlerarası Ticari Tahkimde Tahkime Elverişlilik, İstanbul 2010.

İnceoğlu, M. Murat, Kira Hukuku, İstanbul 2014.

Kaynar, Muhammet, Konut ve Çatılı İşyeri Kiralarında Kira Bedelinin Belirlenmesi, İstanbul 2014.

Kılıç Öztürk, Gamze, Kira Tespit Davası ve Esasları, TBB Dergisi, 2017/129, s. 7.

Kılıçoğlu, Ahmet M., Kira Bedellerinin Dondurulması Yasası ve Eleştirisi, Türkiye Barolar Birliği Dergisi, $2000 / 2$.

Kırmızı, Mustafa, 6098 Sayılı Yasada Konut ve Çatılı İşyeri Kiraları, Ankara 2013.

Koç, Nevzat, 6098 Sayılı Türk Borçlar Kanununda Kira Sözleşmesine İlişkin Olarak Yapılan Yeni Düzenlemelerin Genel Değerlendirmesi, İstanbul Medipol Üniversitesi Hukuk Fakültesi Dergisi 1 (1), Bahar 2014. 
Kuru, Baki, Hukuk Muhakemeleri Usulü, Cilt VI, İstanbul 2001.

Liebscher, Christoph, Objektive Schiedsfähigkeit - Eine Skizze, Dokuz Eylül Üniversitesi Hukuk Fakültesi Dergisi, C. 16, Özel Sayı 2014, Prof. Dr. Hakan Pekcanıtez’e Armağan, 2015.

Münch, Joachim, in: Münchener Kommentar zur ZPO, München 2017.

Nomer, Ergin, Hakem Kararının Kamu Düzenine Aykırılı̆̆ı ve Tahkim Anlaşmasının Geçerliliği, MHB, Cilt 10, Say1: 1-2.

Nomer, Ergin, Milletlerarası Usul Hukuku, İstanbul 2018 (kısaltma: Usul).

Nomer, Ergin, Devletler Hususi Hukuku, İstanbul 2017 (kısaltma: Devletler Hususi).

Ömeroğlu, Ekin, Taşınmazların Kiralanmasına İlişkin Sözleşmelerin Uygulanacak Hukuk, Milletlerarası Yetki ve Milletlerarası Tahkim Bakımından Türk Hukukundaki Yeri, TBB Dergisi 2016 (127).

Özdemir Kocasakal, Hatice, Milletlerarası Tahkim Kanununun Uygulama Alanının Belirlenmesi, Prof. Dr. Özer Seliçi'ye Armağan, Ankara 2006.

Özdemir Kocasakal, Hatice, Doğrudan Uygulanan Kurallar ve Sözleşmeler Üzerindeki Etkileri, İstanbul 2001 (kısaltma: Sözleşmeler).

Özel, Sibel, Milletlerarası Ticari Tahkimde Kanunlar İhtilafı Meseleleri, İstanbul 2008.

Özel, Sibel, Yabancı Hakem Kararlarının Tenfizine Engel Bir Durum: Tahkim Sözleşmesinin Geçersiz Olması, MÜHF - HAD, C. 23, S. 1 (k1saltma: MÜHF-HAD).

Özkan, Işı1/Tütüncübaşı, Uğur, Uluslararası Usul Hukuku, Ankara 2017.

Öztekin Gelgel, Günseli, Milletlerarası Tahkim Kanununun Uygulama Alanı ve Getirmiş Olduğu Önemli Yenilikler, Bilgi Toplumunda Hukuk, Ünal Tekinalp’e Armağan, 2003.

Poloni, Flore, Tahkim Talebine Cevap, Ed. Akıncı, Ziya/Greineder, Daniel/Yasan Tepetaş, Candan, Tahkimde Davanın Açılması: İlk Dilekçeler ve Hakem Seçimi, İstanbul 2020.

Postacioğlu, İlhan, Medeni Usul Hukuku Dersleri, İstanbul 2015.

Rauscher, Thomas, in: Münchener Kommentar zur ZPO, München 2020.

Sezer, Abdullah/Kırıt, Emrah/Boyar, Oya, Hukuk Devleti, İstanbul 2003.

Şanlı, Cemal, Milletlerarası Hakem Kararı-Milletlerarası Ticari Tahkimde Usule Uygulanacak Hukuk Tarafların Tahkim Hukukunu Seçme Yetkisi-Hakem Kararının İptali Davasının Tenfize Etkisi - Tahkim Yeri Ve Mahalli Mahkemeler Arasındaki İlişkiler, MHB, Cilt 3, Sayı: 1, 1983.

Şanlı, Cemal, Uluslararası Ticari Akitlerin Hazırlanması ve Uyuşmazlıkların Çözüm Yolları, İstanbul 2016 (Kisaltma: Ticari Akitler).

Şanlı, Cemal, Milletlerarası Ticari Tahkimde Esasa Uygulanacak Hukuk, Ankara 1986 (kısaltma: Ticari Tahkim). Şanlı, Cemal/Esen, Emre/Ataman Figanmeşe, İnci, Milletlerarası Özel Hukuk, İstanbul 2021.

Takavut, İbrahim Doğan, Milletlerarası Ticari Tahkimde Doğrudan Uygulanan Kurallar, İstanbul 2018.

Tanrıbilir, Feriha Bilge/Şit, Banu, Milletlerarası Tahkim Müessesesi ve Yeni Milletlerarası Tahkim Kanunu, MHB, Y1l 22, 2002.

Tekinalp, Gülören, Milletlerarası Özel Hukuk Bağlama ve Usul Hukuku Kuralları, İstanbul 2020.

Tiryakioğlu, Bilgin, Yatırım Tahkiminde Konu ve Kişi Bakımından Yetki, Ed. Süral Efeçınar, Ceyda/Ömeroğlu, Ekin/Uyanık, Ece, Uluslararası Yatırım Tahkimi ve Üçüncü Kişi Finansmanı, Ankara, 2018.

Tiryakioğlu, Bilgin, Milletlerarası Tahkim Kanununa Göre Hakem Kararlarının İptali, Milletlerarası Özel Hukukta Güncel Konular Sempozyumu, Anadolu Üniversitesi Hukuk Fakültesi, Ankara 2016.

Tunaboylu, Müslim, Kira Sözleşmesinde Fesih ve Tahliye Davaları, Ankara 2013.

Tüysüz, Cemre, Milletlerarası Ticari Tahkim Açısından İcra ve İflas Hukukundaki Davalar, İstanbul 2017.

Wächter, Vincent, Die Schiedseinrede bei Auslandsberührung, Tübingen 2020. 
Wendt, Stephan, Die einstweilige Räumungsverfügung des §940a Abs. 2 ZPO, Tübingen 2015.

von Bary, Christiane Schiedsfähigkeit und Bindungswirkung bei einseitigen Schiedsanordnungen im Erbrecht unter Berücksichtigung der internationalen Perspektive, ZEV 2019.

Yavuz, Cevdet/Acar, Faruk/Özen, Burak, Türk Borçlar Hukuku Özel Hükümler, İstanbul 2014.

Yılmaz, Süleyman/Çavuşoğlu, Gökçe Filiz, Türk Hukukunda Tahkime Elverişlilik Kavramı ve Taşınmazın Aynına İlişkin Uyuşmazlıkların Tahkimde Görülmesi, İnÜHFD (10/2), 2019.

\section{KISALTMALAR}

\begin{tabular}{|c|c|}
\hline AG & Amtsgericht \\
\hline AYM & Anayasa Mahkemesi \\
\hline BATİDER & Banka ve Ticaret Hukuku Dergisi \\
\hline BGE & Entscheidungen des Schweizerischen Bundesgerichts \\
\hline BK & Borçlar Kanunu \\
\hline bkz. & bakınız \\
\hline C. & Cilt \\
\hline ÇAKÜ & Çankırı Karatekin Üniversitesi Sosyal Bilimler Enstitüsü Dergisi \\
\hline E. & Esas \\
\hline Ed. & Editörler \\
\hline HD. & Hukuk Dairesi \\
\hline HMK & Hukuk Muhakemeleri Kanunu \\
\hline HUMK Hukul & Jsulü Muhakemeleri Kanunu \\
\hline İnÜHFD & İnönü Üniversitesi Hukuk Fakültesi Dergisi \\
\hline JA & Juristische Arbeitsblätter \\
\hline K. & Karar \\
\hline md. & madde \\
\hline MHB & Milletlerarası Hukuk ve Milletlerarası Özel Hukuk Bülteni \\
\hline MTK & Milletlerarası Tahkim Kanunu \\
\hline MÜHF - HAD & Marmara Üniversitesi Hukuk Fakültesi Hukuk Araştırmaları Dergisi \\
\hline PPIL & Public and Private International Law Bulletin \\
\hline RG. & Resmî Gazete \\
\hline Rn. & Randnummer \\
\hline s. & sayfa \\
\hline S. & Sayı \\
\hline TBB & Türkiye Barolar Birliği \\
\hline TBK & Türk Borçlar Kanunu \\
\hline Urt. & Urteil \\
\hline v. & von \\
\hline vd. & ve devamı \\
\hline ZEV & Zeitschrift für Erbrecht und Vermögensnachfolge \\
\hline $\mathrm{ZPO}$ & Zivilprozessordnung \\
\hline
\end{tabular}

